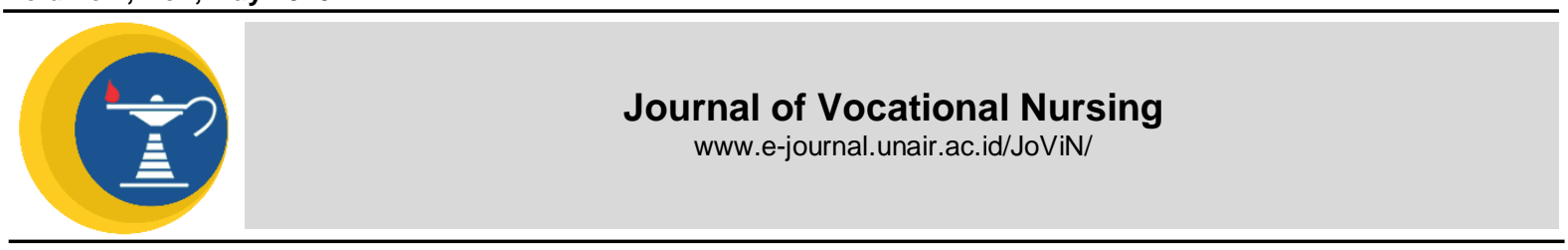

\title{
DOMINANT FACTORS CAUSES OF DRUG ABUSE IN ADOLESCENTS AT THE LAMONGAN DISTRICT PENITENTIARY
}

Research Report

Khotibul Umam ${ }^{1}$ and Agung Prasetiyo ${ }^{2}$

1,2 DIII Nursing Study Program, Departement of Health, Faculty of Vocational Studies, Universitas Airlangga

\section{A B STRACT}

Introduction: The use of illegal drugs is increasing in adolescents and the consequences that will damage the generation so that it must be sought or known influencing factors as preliminary data in determining intervention. According to a preliminary survey at the Lamongan District Penitentiary in 2011, the number of suspects and defendants of drug abuse was 115 people, of whom 63 were teenagers. This study aims to determine the dominant factors that influence drug use in adolescents.

Method: The research design used in this study study uses a descriptive method, namely describing or explaining the factors that cause drug abuse in adolescents. The population in this study were all adolescent drug users in the Lamongan District Correctional Institution in May 2012 as many as 63 people. In this study the sampling technique used was purposive sampling, namely the technique of determining the sample by selecting samples among the population according to what the researcher wanted. In this study the instrument used was a closed questionnaire sheet. Data processing and data analysis by editing, coding, scoring, tabulating and analyzed purposively

Results: Based on the study, several factors were found to be the causes of drug users in adolescents at the Lamongan Penitentiary, including: Social environment (23\%), personality (20\%), family (8\%), education (21\%), and presence Drug (19\%).

Conclusion: Social environmental factors are the dominant factor causing drug abuse in adolescents at the Lamongan Penitentiary.
ARTICLE INFO

Recived 15 December 2019

Accepted 4 May 2020

Online 29 May 2020

*Correspondence:

Khotibul Umam

*Email:

khotibul.umam@vokasi.unair.ac.id

Keywords:

Adolescent, Drug abuse

Lamongan District Penitentiary

\section{INTRODUCTION}

Drug is an extension of narcotics, psychotropic substances and dangerous adaptive substances that are used by the community, produced, supplied, traded, circulated outside the legal provisions. Narcotics include heroin, marijuana, opium (opium), morphine, and pethidine. Whereas dangerous drugs include Locksmith Dealers of America and Ecstasy, Amphetamine, Metanefamin, Mandrax, Rohypnol, and tranquilizers especially from the Benzodiazepine group.

DRUGS can be physically or psychologically damaging, and will result in a deterioration of the body's functions and immune system. Drug abuse is closely related to drug abuse circulation as part of international crime. the increasing supply of illegal drug trade makes people dependent, Relationships between dealers and victims. The fact shows that most people start using psychoactive substances in their teens. However, not all adolescents have the same risk to become users of psychoactive substances. (Joewana, 2005).

According to $\mathrm{WHO}$ around 22,000 people die each year from consuming various drugs belonging to drugs and from drug abuse, the types of heroin (opiates) found a mortality rate (Mortality rate) reaching $17.3 \%$ (Zainal, 2008). Family conditions that are not conducive or in other words family dysfunction has a relative risk (Estimated relative risk) $7.9 \%$ for children / adolescents involved in drug abuse or dependence compared to adolescents educated in a healthy and harmonious family conducive and ignorant of Posyandu is one of 
the family (Broken home by death) has a $26.7 \%$ influence on children / adolescents involved in drug abuse or dependence (Hawari, 2007).

The National Narcotics Agency (NNA) show that in the past five years the number of cases of drug abuse in Indonesia rose by an average of $51.3 \%$ or an increase of around 3,100 cases per year. The highest increase occurred in 2003 as many as 16,252 cases, up $93 \%$ from the previous year, in the same year there were 48,000 suspected cases of drug abuse and in 2008 this case rose to $101.2 \%$ (Ain, 2008).

According to data at the Lamongan District Penitentiary in 2011, the number of suspects and defendants for drug abuse was 115 people. Among the drug abusers above were teenagers as many as 63 people (55\%). From these data shows that many teenagers abuse drugs.

Factors that influence drug abuse in adolescents, namely: Social environment, personality, education, family, and the existence of drugs themselves (Harlina, 2008).

The social environment is the influence arising from the social environment of the actors, both the school environment, association and others. This can happen because the fortress itself is weak, so it cannot stem the negative influence of its environment. In the beginning it might be just a motive to know and try something new, then an opportunity that is possible and supported by the facilities and infrastructure. But over time he was caught up in the snare of drug abuse (Yosep, 2009).

Personality is also one of the factors that can affect drug abuse, where someone with a low self-esteem, emotional instability, and mental weakness. To cover it all and to make it exist, then do drug abuse (lyus Yosep, 2009).

Family conditions that are not conducive or family dysfunction have a relative risk (Estimated relative risk) for adolescents involved in drug abuse or dependence compared to adolescents who live in families who always pay attention to health. Parents have a very important role and can be a strong influence in overcoming drug abuse (Hysmi Fallian, 2008).

Educational factor is a campaign which is needed to provide information on the dangers of using drugs. Lack of knowledge possessed by students will be a result and the dangers of drugs can also contribute to the widespread use of drug users among students (Hysmi Fallian, 2008)

Problems with drug abuse and dependence will not occur if there is no drug itself. In the observation it turns out the availability of drugs and easily obtained both in the official and informal markets. Hawari (2001), in his study stated that the order of the ease with which drugs are obtained (openly, secretly or clandestinely) is alcohol (88\%), sedativa / hypnotic (44\%), marijuana, opiates and amphetamine $(31 \%)$ Furthermore, it was also stated that $81.3 \%$ of them (abusers / drug addicts) were able to obtain drugs by blatant means, clandestinely (72.3\%). $78.7 \%$ of them obtained drugs from the official market and $86.7 \%$ from the informal market.

The impact that can be caused due to drug abuse is that it can relax or reduce the activity of the central nervous system which can cause physical disturbances (trembling, thin body, etc.), psychic or mental (mental disorders, hallucinations, etc.), and social functions that can worsen family condosi which initially was out of harmony, stealing, robbing and even killing just to get money to buy drugs again (Lidya Harlina, 2008).

Action prevention efforts can be directed at two process objectives. The first is directed at efforts to avoid adolescents from an environment that is not good and directed to an environment that is more helpful in the process of adolescent mental development. The government and related institutions should play a proactive role in preventing the use of drugs among generations of youth as the nation's successors because their impact on health will affect the younger generation in the future. Antidrug posters should not only describe the impact of death, but also should be informative in terms of the impact in the short term on the use of drugs. Education on the dangers of drugs in schools is also one form of campaign. Solutions for active users are usually very difficult, need medical assistance and it is important to consult a doctor or rehabilitation center. But if it is not an active user, it can be done by approaching religion and knowledge about the dangers of drugs (Hysmi Fallian, 2008).

\section{MATERIALS AND METHODS}

This study uses a descriptive method, which will be held from January to July 2012 in the Lamongan District Correctional Institution..

The population in this study were all adolescent drug users in the Lamongan District Correctional Institution in May 2012 as many as 63 people. In this study the sampling technique used was purposive sampling, namely the technique of determining the sample by selecting samples among the population according to what the researcher wantedFrom the existing population after being 
selected according to the inclusion criteria, 32 samples were studied.

In this study the instrument used was a closed questionnaire sheet. Questionnaire is a technique of data collection carried out by giving respondents a set of written questions to answer. The questionnaire distributed by researchers used closed ended questions about the factors that influence drug abuse in adolescents which included environmental factors, personality, family, education, and the presence of drugs.

Data processing and data analysis by editing, coding, scoring, tabulating and analyzed purposively so that found the dominant factors causing drug abuse in adolescents at the Lamongan District Penitentiary.

\section{RESULTS}

Table 1 Characteristic Distribution of Adolescents in the Lamongan Penitentiary

\begin{tabular}{ccc}
\hline Caracteristic & Frequency & Percentage \\
\hline Gender & 32 & 100 \\
Man & & 20 \\
Age & 1 & 3,1 \\
$11-14$ years & 3 & 9,4 \\
$15-18$ years & 28 & \\
$19-21$ years & & 100 \\
Marriage Status & 32 & \\
Single & 32 & \\
\hline
\end{tabular}

Shows that 32 respondents (100\%) are all male. Shows that all adolescents aged 20 years and above are 28 people or $87.5 \%$ and a small percentage of adolescents aged $11-14$ years are 1 or $3.1 \%$. Shows that the majority of unmarried adolescents are 17 people or $90.6 \%$ and a minority of widowers are 2 people or $6.3 \%$.

Table 2 Distribution of Characteristics of Adolescents Based on Education at the Lamongan Penitentiary in 2012.

\begin{tabular}{cccc}
\hline No & Knowledge & Frequency & Percentage \\
\hline 1 & Elementary school & 2 & 6,2 \\
2 & Junior High School & 15 & 46,9 \\
3 & Senior High School & 14 & 43,8 \\
4 & Diploma/ PT & 1 & 3,1 \\
\hline & Total & 32 & 100 \\
\hline
\end{tabular}

Shows that almost a number of adolescents have junior high school education that is as much as 15 or $46.9 \%$ and a small proportion of adolescents with PT education are 1 person or $3.1 \%$.

Table 3 Distribution of Characteristics of Adolescents Based on Work at the Lamongan Penitentiary in 2012.

\begin{tabular}{cccc}
\hline No & Job & Frequency & Percentage \\
\hline 1 & Private & 8 & 25,0 \\
2 & Entrepreneur & 14 & 43,8 \\
3 & Job less & 1 & 3,1 \\
4 & Etc & 9 & 28,1 \\
\hline & & 32 & 100 \\
\hline
\end{tabular}

Shows that almost all adolescents work as entrepreneurs as many as 14 people or $43.8 \%$ and a small proportion of adolescents do not work that is as many as 1 person or $3.1 \%$. 
Table 4 Distribution of Causes of Drug Abuse in Adolescents Due to Social Environmental Factors in the Lamongan Penitentiary in 2012.

\begin{tabular}{|c|c|c|c|}
\hline No & Social Environment & Frequency & Percentage \\
\hline 1 & Have an Impact & 23 & 71,9 \\
\hline 2 & No Impact & 9 & 28,1 \\
\hline \multicolumn{2}{|c|}{ Total } & 32 & 100 \\
\hline
\end{tabular}

Shows that most of the causes of drug abuse in adolescents are influenced by the social environment as many as $23(71.9 \%)$ and almost partially are not influenced by the social environment that is as much as $9(28.1 \%)$.

Table 5 Distribution of Causes of Drug Abuse in Adolescents Due to Personality Factors at the Lamongan Penitentiary in 2012.

\begin{tabular}{|c|c|c|c|}
\hline No & Personality & Frequency & Percentage \\
\hline 1 & Have an Impact & 20 & 62,5 \\
\hline 2 & No Impact & 12 & 37,5 \\
\hline \multicolumn{2}{|c|}{ Total } & 32 & 100 \\
\hline
\end{tabular}

Shows that most of the causes of drug abuse in adolescents are influenced by personality factors which are as many as $20(62.5 \%)$ and almost partly not influenced by personality factors which are as many as $12(37.5 \%)$.

Table 6 Distribution of Causes of Drug Abuse in Adolescents Due to Family Factors at the Lamongan Penitentiary in 2012.

\begin{tabular}{|c|c|c|c|}
\hline No & Family Factors & Frequency & Percentage \\
\hline 1 & Have an Impact & 8 & 25,0 \\
\hline 2 & No Impact & 24 & 75,0 \\
\hline \multicolumn{2}{|c|}{ Total } & 32 & 100 \\
\hline
\end{tabular}

Shows that most of the causes of drug abuse in adolescents are not influenced by family factors which are as many as $8(25.0 \%)$ and a small number of family factors also influence the causes of drug abuse as many as $24(75.0 \%)$.

Table 7 Distribution of Causes of Drug Abuse in Adolescents Due to Educational Factors at the Lamongan Penitentiary in 2012.

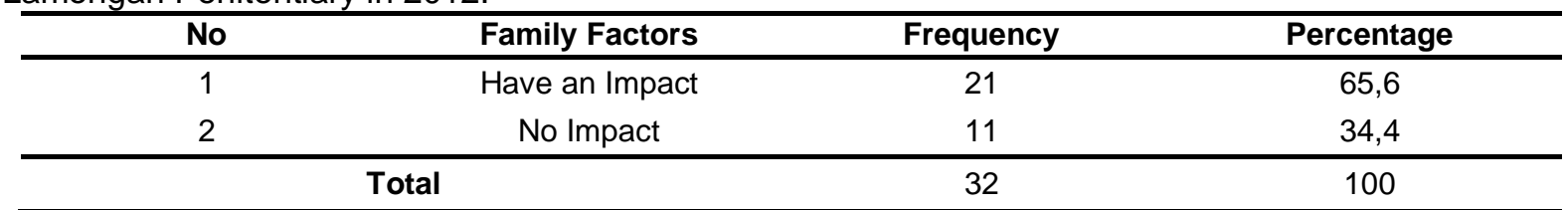

Shows Shows that most of the causes of drug abuse in adolescents are influenced by educational factors which are as many as $21(65.6 \%)$ and almost all educational factors have no effect which is as much as $11(34.4 \%)$.

Table 8 Distribution of Causes of Drug Abuse in Adolescents Due to Drug Presence Factors at the Lamongan Penitentiary in 2012.

\begin{tabular}{|c|c|c|c|}
\hline No & Family Factors & Frequency & Percentage \\
\hline 1 & Have an Impact & 19 & 59,4 \\
\hline 2 & No Impact & 13 & 40,6 \\
\hline \multicolumn{2}{|c|}{ Total } & 32 & 100 \\
\hline
\end{tabular}

Show that most of the causes of drug abuse in adolescents are influenced by the presence of drugs which is as much as $19(59.4 \%)$ and almost partly not affected by the factor of the presence of drugs as much as $13(40.6 \%)$. 
Table 9 Distribution of the domination factors causing drug abuse in adolescents at the Lamongan Penitentiary in 2012.

\begin{tabular}{cccc}
\hline No & Causative Factor & Frequency & Percentage \\
\hline 1 & Social environment & 23 & 25,5 \\
2 & Personality & 20 & 21,9 \\
3 & Family & 8 & 8,7 \\
4 & Education & 21 & 23,1 \\
5 & Existence NAPZA & 19 & 14,25 \\
\hline
\end{tabular}

Indicates that the dominant factor causing drug abuse in adolescents is the social environment.

\section{DISCUSSION}

Social environment, Based on table 4.11 shows that most of the causes of drug abuse in adolescents are social environment. Social environmental factors are the dominant factors causing drug abuse in adolescents. Housing in black or overcrowded areas, tempting entertainment atmosphere, for early teenagers, living habits of people who have activities in entertainment venues and their style less appropriate for children, it is clear that this will have a negative impact. Family has an important role in the education and formation of children's character. From the time of birth the child is cared for in the family, so that the growth and development of his life will not be separated from what is provided and given by his family (Fajar sulistyono, 2009).

Personality Factors, Based on table 4.7 shows that most of the causes of drug abuse in adolescents are influenced by personality factors. Personality is one of the factors that can affect drug abuse, where someone with a low self-esteem, emotions are unstable, and mentally weak. To cover it all and make it feel exist, then abuse drugs (lyus Yosep, 2009).From the data obtained the causes of drug abuse among adolescents are due to the personality of adolescents who experience impaired ways of thinking such as cognitive distortions of beliefs / thinking that are wrong negative thinking / negative outlook, reasoning as they wish, always wanting to try something new and being like a lack of trust self so that it can trigger adolescents to behave negatively so that early education needs to be applied to personality (Hismy Fallian, 2008).

Family Factors, based on table 4.8 shows that a small number of factors that influence drug abuse in adolescents are families. Families can influence a teenager to abuse drugs because the attention of parents and the environment in the family is the basis for the formation of adolescent behavior so that an approach to the family needs to be done to pay more attention to the behavior and association of their children. Family conditions that are not conducive or family dysfunction have a relative risk (Estimated relative risk) for adolescents involved in drug abuse or dependence compared to adolescents who live in families who always pay attention to health. Parents have a very important role and can be a strong influence in overcoming drug abuse (Hysmi Fallian, 2008).

Educational Factors, Based on table 4.9 shows that most education can affect drug abuse in adolescents. Given that schools are also targeted by drug dealers, besides the possibility of schools trying to protect themselves to get good school titles, even though they know there are students who abuse drugs, instead of trying to open up the problem, what they do, on the contrary, cover it for the school's good name credibility of teachers and school leaders (Hismy Fallian, 2008).

Therefore the provision of information about drug hazards must be delivered early and can be done by the government through counseling conducted through education or mass media. A campaign is needed to provide information on the dangers of using drugs. The government and related institutions should play a proactive role in the prevention of drugs among adolescents as the nation's successors because the impact of health will affect adolescents in the future. Anti-narcotics posters should not only describe the impact of death, but rather be informative in terms of the impact of drug use in a short time. Education about the dangers of drugs in schools is one form of campaign. Lack of knowledge possessed by students about the dangers of drugs can also contribute to the widespread use of drugs among students (Hysmi Fallian, 2008).

Presence of Drugs, based on table 4.10 shows that most of the causes of drug abuse in adolescents are influenced by the presence of drugs. The presence of drugs can also affect a teenager to abuse it. Because the presence of these drugs in adolescents affects a teenager to try and abuse them. So that the government needs to implement and provide sanctions in accordance with the laws that apply to drug dealers and users. Problems with drug abuse and dependence will not occur if there is no drug itself. In the observation it turns 
out the availability of drugs and easily obtained both in the official and informal markets. Hawari (2001), in his research stated that the order of the ease with which drugs are obtained (openly, secretly or clandestinely) is alcohol, sedativa / hypnosis, marijuana, opiates and amphetamine. Furthermore, it was also stated that those of them (abusers / drug addicts) were able to obtain drugs in a blatant way, clandestinely as much as they obtained drugs from the official market and from the informal market.

Solutions for teenagers to always get attention from parents, increase religious education, and knowledge about the dangers of drugs.

\section{CONCLUSION}

Based on the results of the research and discussion above, the researchers concluded that social environmental factors are the dominant factors causing drug abuse in adolescents at the Lamongan Penitentiary.

\section{REFERENCE}

Arikunto, S. (2013). Prosedur Penelitian: Suatu Pendekatan Praktik. Jakarta: Rineka Cipta.

Badan Narkotika Nasional, (2009). Advokasi Pencegahan Penyalahgunaan Narkoba Bagi Petugas Lapas / Hutan. Jakarta: BNN.

Fajarsulistyono, (2009). Faktor yang Mempengaruhi Penyalahgunaan Narkotika, Psykotropika dan Bahan Berbahaya. Diakses dari http://www.freewebs.com/fajarsulistyo/f aktor.htm pada tanggal 1 Februari 2012.

Fallian, Hismy, (2008). Narkoba Gelap Euy Seri 1. Bogor: Indobook Citra Media (2008). Narkoba Gelap Euy Seri 2. Bogor: Indobook Citra Media.

Harlina, Lidya, (2008)
Hawari, Dadang, (2001). Penyalahgunaan dan Ketergantungan NAZA. Jakarta: FKUI.

Hidayat, A. Aziz. 2014. Metode Penelitian Keperawatan dan Teknik Analisis Data. Jakarta: Salemba Medika.

Joewana, Satya, (2005). Gangguan Mental dan Perilaku Akibat Penggunaan Zat Psikoaktif: Penyalahgunaan Napza / Narkoba Edisi 2. Jakarta: EGC.

Narendra, Moersintowati B., (2008). Tumbuh Kembang Anak dan Remaja. Jakarta: CV. Sagung Seto.

Nursalam, (2008). Konsep dan Penerapan Metodologi Penelitian IImu Keperawatan: Pedoman Skripsi, Tesis dan Instrumen Penelitian Keperawatan. Jakarta: Salemba Medika.

Sutiyoso, Bambang, (2010). Penyalahgunaan Narkoba dan Upaya Penanggulangannya. Diakses dari http://bambang.staff.uii.ac.id/2008/08/2 6/penyalahgunaan-narkoba/ pada tanggal 17 Januari 2012.

Rahmad, Ridwan, (2008). Akibat Penyalahgunaan Narkoba dan Upaya Penanggulangannya. Diakses dari http://mentoringku.wordpress.co.id/200 8/09/18/penyalahgunaan-narkoba/ pada tanggal 04 Februari 2012.

Soekidjo Notoatmodjo, (2007). Promosi Kesehatan dan IImu Perilaku. Jakarta: PT Rineke Cipta.

Sarlito Wirawan Sarwono. 2012. Psikologi Remaja. Jakarta: PT. Raja Grafindo Persada.

Sofyan Willis, (2008). Remaja dan Masalahnya. Bandung: Alfabeta.

Yosep, Iyus, (2009). Pendekatan Holistik Pada Gangguan Jiwa. Jakarta: FKUI. 